\title{
Engaging Labour: British Sociology \\ 1945-2010
}

\author{
Huw Beynon, Cardiff University
}

\begin{abstract}
This paper traces the interrelationship between changes in the British trade union and labour movement and the development of sociology in Britain since the war. It considers the ways in which both have been affected by economic and political changes and how different patterns of engagement have emerged in times of crisis.
\end{abstract}

\section{KEYWORDS}

Britain, labour movement, Sociology, trade unions, United Kingdom

\section{Post-war Reconstruction, Pre-sociology: 1945-1962}

In post-war Britain the relationship between the labour movement and social research took place through intellectuals involved in the major political parties, with the Labour and Communist parties dominating. The Fabian inheritance of the Webbs continued as did the Mass Observation studies initiated alongside the Left Book Club by the Communist Party in the 1930s. The Census of 1951 recorded 14.7 million manual workers $-64.2 \%$ of the labour force. The trade unions were overwhelmingly based on the industries employing these workers. At this time, for example, there were 730,000 coal miners and the leaders of the National Union of Mineworkers alongside the leaders of the general manual unions (TGWU and GMBW) were major power brokers - 'the

Big Three'. The ending of the war had seen the election of a Labour Government with a landslide majority conducting a major programme of reconstruction alongside a radical transformation of the British state. As such, much research and writing was concerned with questions of industrial reorganisation and the living and working conditions of the working class.

At this time, Sociology was not established as a major discipline within British Universities. This didn't occur until the mid to late 1960s. This period therefore precedes any move to establish sociology as a professional discipline taught across universities and conducting research around agreed fields and topics. There were strong departments at the London School of Economics and at the Universities of Leicester and Liverpool but none elsewhere. All universities however had Extra-Mural departments with extensive programmes of evening classes for local part-time and occasional students, many from the trade unions. E.P. Thompson spent his early career working in such a department as did 
Richard Hoggart Raymond Williams and many others. The form of The Making of the English Working Class (1963) and Uses of Literacy (1957) reflect this grass roots involvement.

Economics departments, however, were more widely distributed as were departments of Social Anthropology. Coal is Our Life (1957) an evocative account of mining life in Featherstone in Yorkshire is one example of a collaboration between sociologist and anthropologists based in Leeds University. Each of the authors (Dennis, Henriques and Slaughter) was very much of the Left - Cliff Slaughter was a leading Trotskyist - and concerned to engage with an audience beyond the academy. In South Wales, Ronnie Frankenberg, as a young communist activist, was employed as a researcher by the National Union of Mineworkers. He returned to the University and became the first Professor of Sociology at the University of Keele. Before this, he published a remarkable account of Welsh social life in Village on the Border (1957). South Wales, at the time, was highly industrialised with a labour movement built around the mining, steel and transport industries. Mining was nationalised in 1947 and (with local MP Aneurin Bevan as Minister of Health) the National Health Service was established in 1948. In this context, coal mining health became a critical issue. The path breaking medical investigations into pneumoconiosis in Cardiff by Archie Cochrane utilised survey techniques alongside the services of coal miners as research assistants. Other research in Swansea drew attention to changes that were beginning to affect the mining communities of South Wales valleys (Brennan, Cooney and Pollins 1955).

The emphasis upon working class community as a social form was a common concern and developed most compressively in London by Michael Young and his colleagues at the Institute of Community Studies. Young's study of Bethnal Green with Peter Willmott - Family and Kinship in East London (1957) remains a classic. However in this work, the authors displayed a significantly different approach that emphasized family and household over other institutions, most especially the state. The influence of Young was to remain a strong and discordant one in relation to the labour movement.

Young was just one example of how, in these two decades, individuals with strong political or religious beliefs and a training in other disciplines were attracted to sociology. Richard Brown for example, was a Quaker. He studied history at Cambridge and was influenced by the seminars on industrial sociology given by visiting US professor George Homans. Concerned to do something worthwhile, and to help establish a new pattern of industrial relations in Britain he took a diploma at the London School of Economics. Successful there, he found no work in industry and was persuaded to take up an appointment at Leicester in 1959. He remembers:

'There was a sort of missionary ethos to sociology in Leicester...I remember thinking at the time it was their religion, they were committed to it in that sort of way, and it had a significance and importance that was far beyond earning a living or doing something that was interesting'.

He also found that: 
'Other people thought sociology had something to tell us so I did a series of lectures at the school of architecture at Leicester Tech because they thought sociologists had the answer to "what we should build and where". (quoted in Roberts 1999:13)

Sociology was also firmly established in Liverpool. Here, under the leadership of Tom Simey (enobled in 1964) empirical investigations into working class life at work and in the community had produced a series of significant monographs in the 1950s. This included The Dockworker: An Analysis of Conditions of Employment and Industrial Relations in the Port of Manchester (1954). This study, led by Joan Woodward and including Enid Mumford on the team, was built around an interview survey which was interrupted by a strike. In a revealing assessment of the trade union, they note:

'They have to accumulate sufficient power to make their bargaining strength equal to that of the employer. They obtained this by increasing the membership by the amalgamations of smaller unions, and by association with the Labour Party in an attempt to reinforce industrial power with political power'. (1954: 116-17)

While this strategy had been successful it had created its own problems, ones written about at length by Michels (1959). In a more psychologised account (of primary and secondary functions) the Liverpool team report a trade union official expressing views to the effect that: 'Dock workers are now well paid. What more can they want?' (University of Liverpool 1954: 117). In commenting on this significant 'lack of insight', sociologists were beginning to highlight issues that were to become central in the following decade

\section{Sociology Ascendant, Labour on the Move: 1962-1978}

In his scholarly and highly informative study of the rise of British Sociology, Mike Savage has noted 1962 as 'the moment of sociology' in Britain. It was the moment when it became clear that the subject was spreading beyond its three isolated centres and that this trend would continue with the growth in the university sector itself. Encouraged by the election of a Labour Government in 1964 Sociology departments opened on a regular basis through the decade with the recruitment of large numbers of staff - many of them drawn (in one way or the other) from one of the older centres. As a reflection of this development, and instructive as to its significance, was the creation of a new weekly journal: New Society. As Savage makes clear:

'Its novel cause was to promote popular social science to a wide audience of policy makers, educated professionals, and the broader reading public. Numerous weekly journals pitched at this audience already existed, but none of them had ever seen the propagation of the social sciences as their main concern'. (Savage 2010: 112) 
The clear concern of the new weekly journal was to provide the social counterpart to the successful New Scientist. In providing an outlet for research papers from the new cadre of sociologists, New Society hoped to both professionalise the infant discipline and provide state practitioners and policy makers with the scientific evidence that would support them in their endeavours.

As such, during the 1960s the subject had moved rapidly from being a comparatively new discipline of Sociology to one with strong departments and large numbers of students across the higher education sector. It expanded in the context of a highly organised labour movement made up of strong trade unions, a Labour Party with half a million members, a highly influential Communist Party and a variety of Trotskyist and syndicalist groupings with areas of strength within communities and trade unions and most especially on campuses, within campaigns and demonstrations. In 1968 the events in Paris had placed universities and their student populations at the centre of political unrest and dissent. All of these elements were present in Sociology Departments in this period. Pressures to professionalise the new discipline were matched by others insisting on its public role and the need to engage with issues raised by the labour movement in, what was a telling phrase of the time - 'the real world'. As a result Sociology in the UK emerged as a relatively open but theoretically contested arena and one that was increasingly attractive to dissidents in cognate social science areas, such as Industrial Relations and Economics.

The labour movement in the 1960s was an intriguing combination of the 'old' and the 'new' - sometimes described as 'traditional' and 'instrumental' forms (Lockwood 1966). Unionisation was high, with membership reaching an historical peak in 1976. While the seventies are often written about as a grim decade, other interpretations are possible (Beckett 2009). British people scored most highly on measures of 'happiness' at this time! 


\section{Trade Union Members: UK}

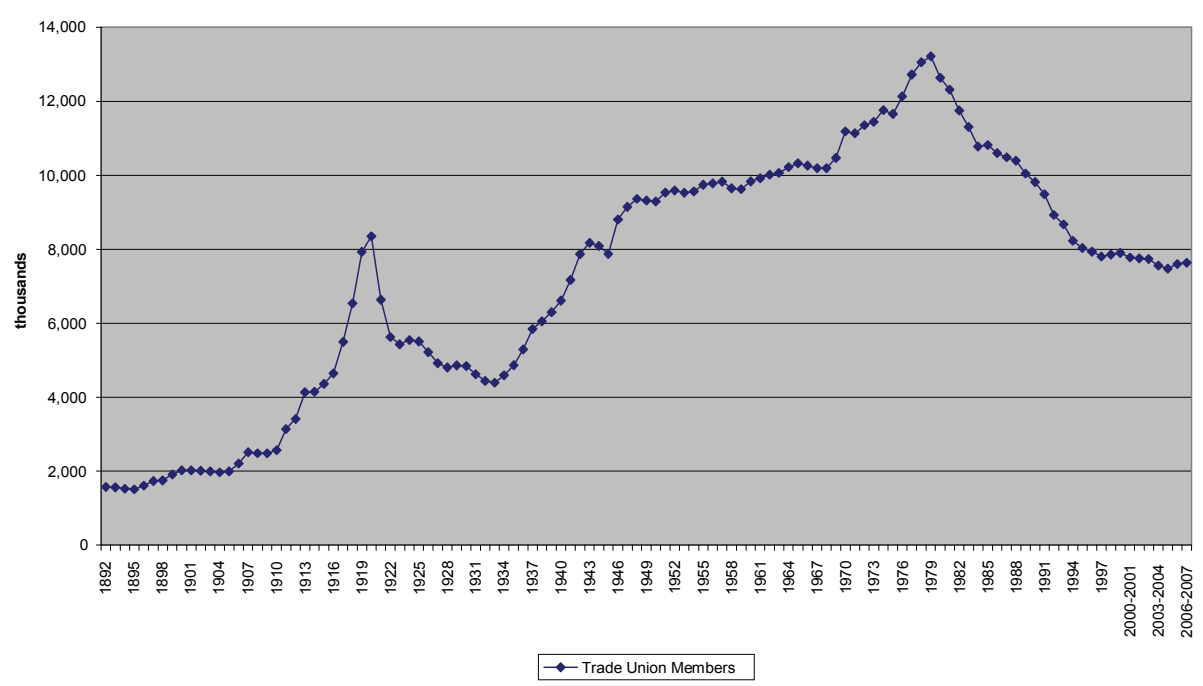

Source: Office of National Statistics

The old established industries of coal, steel and transport, whose trade unions had made up the Triple Alliance, remained highly unionised. In the coal industry the NUM was guaranteed by Act of Parliament. These industries, especially coal mining and dock work, had been identified as 'strike prone' and as such were the focus of some research in the fifties. However during the 1960s their size was much reduced. In this period the old industrial regional economies were dismantled through coal mine and railway closures, with over 400,000 coal miners made redundant and many others transferred to other coal fields. There was no hint of this - of what was to come - in the pages of Coal is Our Life, which for all its brutal detail of the work, read then (and now) as a world of enormous stability. However - and in a way that presaged the future - it was a world that was coming apart. This contributed to the renewal of militancy and the emergence of mass national strikes in the mining areas, as well as on the docks and in the steel towns, and amongst the print unions whose industry was to become emblematic of change in the 1980s.

In the sixties and seventies however, these were not the focus of social science or industrial sociologists. In the North East of England Richard Brown conducted an important study of the changing experiences and outlooks of workers in the ship yards of the Tyne (Brown and Brannen, 1970a and1970b). There was interest in the workings of the Redundancy Payments Act, and the facilitating role that this played in work place closure, something that was to gain in significance later. There was also a recognition of poverty and displacement within the inner city areas. The most important and enduring study of this kind detailed wages and living conditions in the St. Anne's area of 
Nottingham and stress the significance of low wages rather than unemployment as the root of poverty (Coates and Silburn 1970). Recognition of the disturbance taking place in local labour markets and the associated patterns of economic migration was central to Margaret Stacy's (1960) early study of Banbury and had been one of the defining features of Goldthorpe and Lockwood's study of Luton (1968a, 1968b, 1969). In its final form however The Affluent Worker study became more an account of changes in 'orientation to work'. Concerned with popular conceptions that workers though affluence were becoming middle class (embourgeosified) the study documented the persistence of working class forms of life established though a growing instrumentalism amongst workers detached from 'traditional' ties of solidarity and kinship. This study was a major event and its emphasis on 'money' was to be to be taken up by the 'new trade union movement' of the eighties as the more right wing unions began to emphasise the provision of financial and other services rather than organisation and mobilization.

In contrast a growing number of sociologists were less interested in examining 'orientations' than documenting the direct experiences of workers in the new mass production industries of automobiles, white goods and food packing. Set up in the thirties (often by US capital) these industries grew rapidly, often employing increasing numbers of women workers. This was achieved though the expansion of existing establishments and through the state driven location of new plants in the old industrial regions of the North and West. Unionised during the war they formed the dynamic centre of trade union growth in the sixties when they were also the centre of militancy and a wave of strikes that were often fuelled by the 'lack of insight' identified by the Liverpool researchers. Although the UK was not significantly strike prone when compared with other similar countries (Turner 1963) they were sufficient for the 1964 Wilson Government to establish its ill fated Royal Commission inquiring into the trade unions. This identified, amongst other things, the emergence of shop steward committees as parallel unions operating within and outside the official structures. The automobile industry was at the centre of these developments. The British owned sector of the industry dominated the market but though a fragmented set of production plants and an unsophisticated managerial style (Turner et al 1967) its main competitors were the expanding operations of General Motors (as Vauxhall) and Ford. One of Vauxhall's plants was based in Luton, and workers there had been part of the Affluent Worker study. There were other studies of car plants in new locations (Beynon 1973). All of these writings appeared in some form in the pages of New Society. One - 'A Wildcat Strike' (Beynon 1968) - documented the ways in which the introduction of unregulated paced assembly line work in Liverpool clashed with a strong labour movement linked to the docks.

Further studies followed. Based in Liverpool, Tony Lane and Ken Roberts produced a detailed account of the changes that led to an outbreak of labour discontent at the paternalistic glass producer in nearby St Helens. Strike at Pilkingtons was published in a Fontana paperback and widely distributed on the high street. Soon after, Working for Ford was published by Penguin Books and sold out within a year. This account paid particular attention to the historical development of the industry and the patterns of resistance and forms of trade union organisation that emerged at different points. In the UK in the seventies the emphasis was upon the capacity for local factory leadership (shop 
steward committees) to link up with each other to engage in national strikes and patterns of international solidarity action, including boycotts. This was occurring at time when there was major debate amongst sociologists on the nature of corporatism as a form of governance. Within Marxism corporatism came to be seen as a form of governance critical to the survival of capitalism and far less benign than the Labourist view of 'tripartitism'. In this context, many of us saw movements 'from below' as an essential dynamic to progressive change within late capitalist society. Although often cited as a 'classic study', at the time Working for Ford was not reviewed in either Sociology or The British Journal of Sociology.

At this time, and in a process not unconnected with the rundown in the old established industries, dramatic changes were taking place in the gender composition of the labour force. A strike by sewing machinists at Ford in 1968 drew attention to this phenomenon and raised broader questions of equality of payment and treatment. The actions of these women in Dagenham and Halewood alerted the Labour Government to the need for legislation; it also drew feminist sociologists into the factories. Here as they talked and worked with women in cigarette, clothing and food packing factories in different sites around the UK (Pollert 1978, Cavendish 1978) new perspectives on work and employment emerged and with it theorisations of patriarchy and capitalism (Walby 1986).

The ongoing decline in the proportions of work force involved in heavy manual work saw technical and white collar jobs were emerging in significant numbers. Many of the old established trades of draftsmen and tracers were being threatened by technical change and what became referred to as 'the chip'. Technical change, combined with corporate mergers accelerated the move into trade union membership and the rise of trade unions like ASTMS and TASS under the prominent left wing leadership of Clive Jenkins and the Communist Ken Gill. These developments contributed to further conceptual development and analyses on a 'new working class' (Hyman and Price 1983).

A third group of workers, and one of growing importance, worked in the public services and they too were increasingly female. The public sector had expanded enormously since the war and this had been associated with trade union recognition. The National Union of Public Employees (NUPE), for example, was firmly established within the health and local authority sectors with a strongly female labour force, many of whom engaged with trade unionism for the first time (Cunnison and Stageman 1994). Here other significant social and political issues emerged. The development of militant trade unionism emphasising strike action raised in new ways tactical and strategic issues over the relationship between 'producers' and 'consumers'. Could employees in responsible positions of care take strike action that risked damaging other vulnerable (working class) people? How should public sector workers relate to 'the public', and how should they understand their relationship with their employer - the state? This debate was developed further though the public engagement of sociologists working for the state.

In 1969 the Home Office established a Community Development Programme CDP) in twelve locations aimed at monitoring industrial and social changes in some of the most deprived parts of the country. These programmes employed sociologists who worked with local communities. In 1977, through an inter-project development team 
they produced a report called 'Gilding the Ghetto' that was circulated in pamphlet form and criticised the ways in which the programme was being used to gloss over the structural underpinnings of poverty. Soon after, another group identified as the London to Edinburgh Weekend Return Group (1979) produced another insider account. In and Against the State identifying the contradictory position occupied by many state workers.

In this period therefore trade unions played a central part in British society. Each national newspaper employed more than one journalist devoted to following labour issues. The 'bosses paper', The Financial Times had a team of labour reporters who followed the inner workings of the trade unions in careful detail. The paper carries a daily calendar on its front page of the important meetings and events of the day, and in this period the meetings of the National Executive Committee of the National Union of Mineworkers were always included. The importance of the NUM related to its power. After the mine closures of the 1960s the trade union had been largely ignored as a source of influence within British politics. However this was all changed by OPEC. In 1972, under a Tory Government, the coal miners launched a national strike over wages that had a significant effect upon electricity supplies. The strike was eventually settled after a national inquiry that decided firmly in favour of the trade union's demand. A further strike followed in 1974 during which the Prime Minister Edward Heath determined to settle 'who runs the country' called a general election, which he lost. Under the new Labour Government the NUM was ascendant and with it a new form of class politics was emerging with new and unusual organised forms of solidarity action. This was perhaps made most clear in the Grunwick dispute in $1977 .{ }^{1}$

Harry Braverman's Labour and Monopoly Capitalism: The Degradation of Work in the Twentieth Century was published in 1974. Coupled with events 'on the street' it produced a period of intense engagement with the both the theory of work and employment change and the direct experiences of workers. Much of this found itself into the pages of the new journal - Capital and Class. Established in 1977 out of the 'Conference of Socialist Economists' it was committed to 'developing a material critique of capitalism in the Marxist tradition within the labour movement and other movements of liberation'. Seeking to overcome disciplinary boundaries the journal provided an outlet for papers across the social sciences detailing empirical researches and engagements with the labour movement. Re-reading these pages is a reminder of the unfolding issues relating to the 'British crisis'. Bob Fryer wrote in Issue 4 on the state of trade unionism in the public services, and followed in Issue 8 with a consideration of how these unions could develop a strategy to engage with 'the cuts'. Richard Hyman considered problems facing work place trade unionism, Jim Tomlinson addressed the question of worker cooperatives and Jane Baker and Hazel Downing consider the impact of the word processor on patriarchal relation in the office. Capital and Class was later joined by Marxism Today, the re-launched journal of the British Communist Party, providing a further avenue for sociologists and others to be part of a broader public debate within the Labour movement. 


\section{The End of Illusions: Labour in Retreat: 1978 - 1990}

By 1980, the discipline of Sociology was taught in departments in universities across the sector. Here the study of work and labour was firmly established with strong links with the study of industrial relations with its powerful base in the LSE. This strength was represented in a number of ways. The ESRC, for example, established the Industrial Relations Research Unit at the new university of Warwick in the industrial Midlands of England. In addition and after considerable lobbying, a Workplace Industrial Relations Survey (WIRS) was established in 1980 with the aim of gathering information from management and employee representatives across 2,000 establishments in the UK. WIRS 1980, as it became known, was followed by four others producing 'the major and most consistent set of time series data on British employment relations' (Stirling 2001). A further indication of the importance of issues of labour within Sociology was to be seen in the creation of another new journal. Work, Employment and Society was set up in 1986 by the BSA after considerable discussion, with Richard Brown as its founding editor. The established journal of the Association - Sociology - was being overwhelmed by the increasing volume of papers being presented for publication from the growing number of sociologists employed in academic posts. Its choice of title was a mark of the historical strength of this area of inquiry within British sociology and also its openness to cross disciplinary research. All this was, of course, taking place at a time of momentous change and industrial upheaval (see Gardner 1988).

In 1976 Britain had faced a devaluation crisis that involved the assistance of the IMF. This assistance did not come without strings. The IMF imposed conditions that committed the Labour Government of James Callaghan to public sector cuts of $£ 8$ billion between 1977 and 1979. The view on Wall Street was that the British economy and its trade unions had 'run out of rope' (Burk and Cairncross 1992). In the face of this, and ignoring advice from trade union leaders to take an early election, Callaghan delayed. What followed was a 'winter of discontent' of wage cuts and highly publicised public sector strikes with stories of uncollected rubbish and the unburied dead. All this laid the ground for a victory for the Conservatives under Margaret Thatcher in 1979.

The years that followed had profound effects upon each of the three strands of the labour force. They begin with massive closures in manufacturing and with labour sociologists working with local groups and writing about de-industrialisation, anti-closure campaigns and the relationship between the work place and the local community. These early years are featured by a sharp decline in trade union membership and numerous examples of aggressive anti-trade union behaviour by employers, especially in the print sector where the new technologies and the new employment laws allowed for major transformations, but also across engineering with major closures in automobile manufacture.

These years also revealed the power that lay in rhetorical devises expanded and emphasized through the popular media. In the eighties, as large swathes of manufacturing were laid to waste, television created characters who emphasized the money that could be made though dodgy dealing and being fly - 'loads of money' became a phrase that caught on. More generally Thatcher and her cadre of politicians increasingly denigrated 'the 
past' and the out-of-datedness of certain practices and ways of being. Tony Blair was to embellish this as we shall see. Here trade unions and their leaders were identified with a bygone age. For example the dock workers' trade union was identified as 'the last of the great medieval guilds' and the dock workers themselves as 'fossils amongst a wasteland of their own creation' (see Turnbull, Woolfson and Kelly 1992). Trade union leaders were so commonly referred to as 'barons', that it became a part of everyday speech. Other allusions were toward the Mafia, and attendant notions of power and corruption. Together these ideas combined to identify trade unionism, (and by extension, notions of the working class) as essentially out of date and living in the past. Newspaper headlines commonly associated the trade union leaders with dinosaurs. This reference became more common after Spielberg's movie Jurassic Park. In factories, and offices trade unionists and leftists came to be referred to by management as 'the Jurassics'. Changes such as these were theorized more broadly by Stuart Hall and colleagues though the pages of Marxism Today, identifying the ways in which 'Thatcherism' had given emphasis to powerful forces of individuation that threatened collective forms of action (Hall and Jacques 1983). They also contributed to Hobsbawm's view of The Forward March of Labour Halted.

There is reason to think that these concerns were exaggerated. In spite of compelling evidence (Turner 1963, Hyman 1972) policy makers held to the view developed in newsprint that the UK was excessively affected by strike action and that the British worker was at the root of the country's problems. Nichols identified this as the 'background music' of the post war years and in his powerful analysis of The British Worker Question (1976) demonstrated its many fallacies. While reviewed enthusiastically this account was also ignored, by governments and also by many sociologists.

The context of all this was a set of changes that added up to the most fundamental transformation that has ever taken place in the structure of British industry. Between 1979 and 1982 employment in manufacturing was almost halved as 3 million jobs were lost though the closure of factories. As a consequence, and in contrast to the offensive strikes of the previous period, workers and trade union organisers became preoccupied with defensive struggles aimed at resisting a major 'closure movement'. In this period while trade unions were pressed into offering 'concessions' to employers, there were numerous examples of opposition. Some workers occupied their factories and were involved in broader campaigns aimed at highlighting the public consequences of a private closure.

The closure movement was remorseless and sociologists were involved in different ways. In Kilmarnock a group of sociologists' from Strathclyde University began working with the shop stewards' committee of Massey Fergusson Glasgow in 1977. They became centrally involved as advisors as the committee attempted to develop a strategy to deal with the global strategy of the employer. An account of their experiences was written up in Capital and Class (Baldry, Haworth, Henderson and Ramsay 1983a and 1983b). On Merseyside, Tony Lane worked closely with the shop stewards committee at the Dunlop factory in Speke, producing papers and reports on the capacity of the company to move jobs to different sites across Europe. He was later seconded from Liverpool University to work with the Transport and General Workers Union (TGWU) on issues relating to employment and plant closures. His article 'Unions on the Ebb Tide' was published in 
Marxism Today and (in the way it drew attention to the ways in which companies had integrated shop stewards through facility time) was the cause of major controversy.

Merseyside was one of the areas being particularly badly hit and the closure of British Leyland's car manufacturing plant at Speke in 1981 had been seen as emblematic of the change that was taking place in and for the labour movement. After what were seen as a series of provocative actions by local management, the strong shop steward's committee organised an aggressive strike. In the first week of the strike, the company announced that the plant would close, effectively locking out the strikers, who were made redundant. These workers formed themselves into an 'unemployed workers' branch within the union and approached me to write an account of What Happened at Speke. This was published as a pamphlet by the branch, and a condensed version appeared in New Society (Beynon 1978). Here the emphasis was upon changing times and the need for a change of strategy - don't vacate the premises without thinking!

The North East of England was another of the old industrial regions hit by closures. Here Sociologists based in the University of Durham worked closely with the General and Municipal Workers Union (GMWU) and produced an account of union organisation within the plants of multinational corporations across the area. This report, Global Outpost was widely distributed within the union (Austrin and Beynon 1978) and reached almost Samizdat proportions as further copies were photocopied on demand. Through discussions with rank and file workers this report documented the ways in which effective decision making no longer took place within the region but in headquarters located across the planet. Furthermore workers in each of the corporations were beginning to see themselves less as part of a Northern working class and more as employees locked into a transnational corporate hierarchy. This led to discussions on the appropriate kind of trade union organisation and response, one of which was the shop steward combine committee.

Within one company with factories in the North East (Vickers) there had been an attempt by the shop stewards' combine committee to challenge the corporation through the development of 'alternative plans'. This was particularly appropriate in the context of a major British arms producer, and the notion of such alternative plans were also developed at Plessey's and were taken up for discussion within the Institute for Workers' Control - run at the time by Ken Coates and another location for sociologists to link up with the labour movement. While these initiatives around the uses of technology and human capacity were not wasted and have a continuing impact (Cooley) they were not effective in preventing factory closures. After a long campaign involving a broad range of support, Vickers' Scotswood factory in West Newcastle was closed (Beynon and Wainwright 1983).

Reflecting on these matters at a conference in Newcastle, Tony Lane argued that: 'we're not talking about the closure of factories we're talking about a closure movement' (Lane 1982: 29). He reported on his experiences at Dunlop's, a plant which he described as 'the best organised factory of any within the TGWU, and quite possibly the best of any factory in Britain' (Lane 1982: 27). After a lengthy campaign involving visits to workplaces across Europe the factory closed. While he spoke sympathetically of alternative plans and planning agreements he was clear in his view that trade union organisation was completely unprepared and incapable of mounting a concerted response 
to the closure movement. As if to emphasise the point a year later, the print union SOGAT made a serious attempt to prevent the closure of Fleet Street with a concerted mass picket at the newly opened non-union print works in Warrington. It was dealt with by the full power of the police.

The closures in the early eighties differed remarkably from what had gone before, where closure has been in the form of an extended lay-off followed by a re-opening. These closures were for good, and were less a response to fluctuations in the national market place and much more to do with the spatial reorganisation of production. As such the closures, and the trade union response, had a significant impact upon the way sociologists began to theorise work, employment and trade union organisation. Previously work places had (to an important extent) been taken as given and 'a job' was mostly understood by sociologists and trade union activists as something involving 40 hours a week, perhaps with shift work and most likely performed by men. By the mideighties none of this was sustainable. Already it had been clear that it was it not possible to talk about 'work' without considering issues of gender and domestic work, issues of work place segregation and part-time working. But now it was also evident that location decisions were clearly important, as was the need to situate factories and offices within chains of production. In this Braverman alone was not enough. Theories of deskilling could not help provide an understanding of the critical issues facing the labour movement, or how the interests of one group of workers could be weighed against others. This needed a spatial dimension, and collaborations with geographers became commonplace, as work and place became reunited. This was before the great coal miners' strike of 1984-85.

In 1983 the coal miners elected a new President. Arthur Scargill was President of the Yorkshire Area of the NUM. Before joining the Labour Party, Scargill had been a young communist and had been active in the strikes of 1972 and 1974 . He, along with many other young miners had attended courses at Leeds University and had been influenced by the teaching and writings of Vic Allen. In debates in the early eighties with Ken Coates and others Scargill had made clear his disagreements with the Institute of Workers' Control. In his view alternative planning only succeeded in drawing the trade union into the employers' realm. The way forward, in his view, was to challenge the employer and the state with trade union power. He had evidence in is support. In 1981, when factories were being closed all over the old industrial districts, the National Coal Board announced its intention to close coal mines. This provoked immediate strike action in South Wales, followed sporadically across the other coal fields. In the face of this reaction the closures were withdrawn. Three years later, however it was a different story, with a more confident Thatcher government (after victory in the South Atlantic and in the general election) and a well prepared state. The NUM supported a dispute over mine closures that rolled through each of its Areas. Federal in structure, the national union's executive supported the developing strike and resisted calls for a national ballot (see Beynon 1985). The issues here were complex, undoubtedly the decision became a source of argument and criticism of the union. The strike lasted a year and ended with the NUM recommending a return to work 'without an agreement' in March 2005.

Before the strike erupted the NUM had learned many lessons from the closure of the manufacturing plants. The miners' union employed research and education officers 
who linked with groups in the universities to produce documents for a Campaign for Coal. The logic of the Campaign centred on the need to build a broad based coalition of support for the coalminers in their defence of jobs. It produced a series of discussion papers held together in large maroon envelope folders. In this way, details of employment multipliers and the impact of closures on local communities were brought together with papers dealing with energy policy and the threats posed by nuclear reactors. They formed the basis for discussions around endless evening meetings across the coalfields of the UK and were helpful in producing extremely well informed cadres of local activists capable of arguing and debating the case for keeping coal mines open. They also extended the Campaign beyond the coalfields and the strike itself produced a multiplicity of 'twinning' arrangements between the mining towns and villages and other local groups and communities - sociology departments figured centrally in this. Ultimately the strike was sustained through coordinated community activity and women were centrally involved and critical to this. During the strike feminist sociologists linked up with the Women Against Pit Closures movement with Jean Macrindle from Northern College in Yorkshire, acting as its Treasurer. As winter approached in 1984 a group of us collaborated in producing a book that built on the Campaign for Coal and explained the reasons for the strike (Beynon 1985). After the defeat, when mine after mine faced closure, sociologists and economics worked together to produce analyses of the consequences of closure, analyses that were followed up with empirical 'after the fact' investigations.

In a way, the miners' strike and closure of coal mining brought together all the elements of collaboration between sociology and the trade unions. At moments it seemed possible that the combination of the Campaign, the strike and the involvement of women's groups and local communities would counter the weakening and oppositional forces associated with the ideological shift that had been termed Thatcherism. At an Open University workshop in London, Stuart Hall contrasted the involvement of the miners' wives in the dispute with the ways in which 'wives' had been used in media campaigns against strikes in other industries. But it wasn't enough. The strike was defeated and the defeat was a major political moment.

While the strike remains a firm part of popular memory in the mining areas, the consequence of its failure are still being lived though. The coalfields have been transformed. Following the return to work there was a mass closure of the coal mines. Completed in two phases the entire coal fields of South Wales, Durham, Scotland, Kent, Lancashire, Derbyshire, Leicestershire and Staffordshire were wiped out. The remaining mines in Nottinghamshire and Yorkshire are isolated remnants of previously extensive regional economies.

More generally the fact that coal miners had followed steel workers, dockers and ship yard workers into oblivion had a corrosive impact upon ideas of class politics and organised trade union solidarity. The hard organised centre of the trade union movement had gone, along with the millions of union members in the large manufacturing plants that one time symbolised Britain. This opened the door for New Labour and the politics of the future, based on a Third Way (Giddens 1998).

As in the US, the core of trade union membership came to be centred within the public sector and this was made emblematic in the formation through merger of three 
public sector unions in to one - UNISON - that would become the largest union in the UK. In the development of this merger, Bob Fryer who has a long standing relationship with NUPE acted as a facilitator between the three merging unions linking with Mike Terry (close to NALGO) and Mick Carpenter (COHSE). In this the question of union democracy was an important issue and the new union's constitution and rule book was radical in the way it recognised the diversity of the work-force. In providing representation and group organisation on the basis of gender, ethnicity and sexuality, the new union was seen to have established a new model for union organisation.

\section{New Forms of Labour - New Studies of Work: 1990-2010}

The shattering of the core of the organised manual working class was exacerbated by new forms of contract, shift working and longer distances of travel to work. Changes in patterns of migration also affected this, with the arrival of new migrants from the enlarged EU. The scale of the changes were measured in many ways. Return studies and revisits were an interesting form. One was done in Bethnal Green (Dench, Gavron and Young 2006) and the authors make plain the near total transformation that has taken place in the East End of London since the 1950s. Here the story is of the displacement of people and of new arrivals; of racism, poverty and discord over housing and public resources. While an important document the book marks the end of the trajectory of Michael Young's work. Published after his death it places the source of the problems of local people firmly at the door of the welfare state and developments that were put in place in the forties (Beynon 2007). This has also been the trajectory of one of the authors on Coal is Our Life, Norman Dennis. However, the re-examination of life in Featherstone by Royce Turner (2000), has a different focus. Here he examines the disappearance of the coal industry with the resulting patterns of joblessness, bad jobs and social disharmony. A second edition of Working For Ford published in 1985 had documented the ways in which the management regime at the company had changed in reaction to international competition. First it attempted to tighten its grip and then, when this failed, it developed a new participative approach. In the end, car production ended at Dagenham and the much reduced Halewood factory was taken over by the Tata group to produce Land Rovers.

In the face of these changes, and the decline of a politics of the working class, sociological interest in work and labour waned (Rose 2001). While in previous periods an engaged working class presence made inequality and class consciousness unavoidable, the quietism and defeat of this period saw these issues slip off the agenda. There were other casualties. The advertising revenues of New Society fell and it was taken over by the political weekly New Statesman in 1988 and produced as the New Statesman and Society with a joint editorial board until 1996, when 'Society' was dropped from the title. Marxism Today ceased publishing in 1991 and it too was incorporated informally into the New Statesman.

At the same time, major changes were taking place in the organisation of research within higher education. Here, an increasingly complex Research Assessment Exercise was used by many universities to regulate more closely the kinds of research conducted 
and published by its staff. To this was added the proliferation of new data sources, and research institutes within the private sector, competing with university departments for grants and consultancies. This was matched by the continued, long term rise of Business Schools as the locus of industrial and trade union research within the University sector.

At one BSA Annual Conference, I chaired a panel discussion on the state of industrial sociology within British Universities; all of the other panel members worked in Business Schools of Schools of Management. The inquiry into the state of British social science set up by the Academy of Social Sciences (2003) noted that 1 in 8 students in the UK studied Business and Management in one of the 110 Business Schools that were emerging as growing centres of employment for social scientists in universities. In considering the place of the sociology of industry and organisations within British Universities, the 2008 UK Research Assessment Exercise commented than 'much of this work is now concentrated in Business Schools, a trend apparent for many years'. It added however that:

'Work in these areas continues within sociology departments, however, but transformed into new specialisms...This reflects a key feature of sociological work, which is to alter its pattern of research specialisms to respond to contemporary concerns'. (www.rae.ac.uk)

This is an important caveat. Some of the changes that have taken place to the sociology curriculum have simply been a response to student preferences. As one experienced teacher from Warwick University put it in 1990: 'the students won't sign up for sociology of work course; so we have to call it something else'. Equally important has been the fact that changes in the form of the working class, the complexity of racism and the new spatial organisation of capitalism, required a reoriented sociology of labour. There are signs that this is emerging and along with it, different kinds of links both with Labour organisations and other disciplines.

In this period, and especially since 1997 and the establishment of a New Labour government, the trade unions have had the space to re-assess their role and their future strategy. The hope (which proved to be unfounded) was that the employment legislation of the Thatcher governments would be repealed or amended. Linked to this was a strategy for growing the trade union movement after twenty years of retrenchment. One part of this strategy involved mergers and we have noted the role played by Bob Fryer in the UNISON merger of public sector unions. Learning from this many others followed including the unions of the bank workers, civil servants and rail and marine transport workers. The biggest and perhaps most important merger was the one that brought together the TGWU with the engineering union AMICUS to form UNITE the Union.

These mergers were driven forward by the financial problems associated with membership decline. They were linked with strategies of membership recruitment something which became known as 'organising'. This was one aspect of a debate over trade union 'renewal' conducted within sociology departments and in Business Schools (Heery, Fairbrother). ${ }^{2}$ What this concern with organising also made clear was that trade union density varied across the different regions of the UK. In part this related to variations in the composition of the labour force, but there is also the possibility of real 
'regional effects' that might be encouraged by processes of political devolution, and different patterns of activism.

This variation is matched within the social sciences. At a number of places universities possess strong clusters of researchers linked actively with the trade union and labour movement through an engagement in the study of work and employment. Cardiff is one such place but others would include London, Strathclyde/Glasgow, Leeds and Warwick. In Cardiff for example, the Seafarers International Research Centre (SIRC) established with funding from the ITF, focuses on the international organisation of shipping and the implications for seafarers and their trade unions. Alongside SIRC, Peter Fairbrother and Ed Heery linked the School of Social Sciences with the Business School to set up a Centre for Global Labour Studies (CGLS) with the aim of linking local and national studies of labour with ongoing international developments.

This emphasis on the global reflected the persistent pattern of outsourcing manufacturing and service activities outside the UK. Something that has been matched by the foreign ownership of British firms, and thepersist use of migrant labour on temporary contract across a number of sectors as the volatility in the organization of production was extended to labour markets. The hotel and catering industry in London, for example, became organised around female migrant workers recruited though employment agencies in what Jane Wills has termed a 'migrant division of labour' (Wills and Datta 2010).

Jane Wills, of course, is a human geographer and she is one of many who have worked on issues relating to labour and trade unionism over the past twenty years. Her Fabian pamphlet Union Futures (2002) promoted discussion of ways in which trade union networks could be developed across the UK and contributed to a widespread debate over new ways of organising. In this context, sociologists (as with researchers in Business Schools) have developed positive inter-disciplinary collaborations. In London joint working has supported the push with trade unions for a London Living Wage, a campaign which moved discussion beyond the idea of a 'minimum' and toward recognition of the costs of living in the city. In Wales there has been a focus on the public sector based on the close links with UNISON developed by Steve Davies and others. Here collaborative activities have focused on the potential for a more radical use of Social Clauses in public sector procurement contracts and active engagement with the nature and importance of 'public goods'. Davies (2010) combined with UNISON in a broad campaign to establish the importance of public lending libraries. These campaigns echo those of the miners thirty years ago in their attempt to build alliances between workers and consumers against capital and state restructing.

This is the context in which the trade unions and the social sciences in the UK face a further major challenge. In the fall out of the financial crisis and the formation of a Conservative-Liberal coalition, massive cuts in public expenditure are planned. In this current estimates are that over a million workers will be made redundant. While these job losses will hit public sector workers directly, as a consequence of out sourcing and other procurement practices, private sector workers will be hit equally hard. With UNITE the Union locked in a struggle with British Airways - a company set upon driving down wages and breaking the union's hold on Heathrow - the talk, once again, is of a 'fight for survival'. However it is in the public sector, where trade unionism is strongest, that the 
new coalition government will launch its sustained attack on jobs and this is where resistance will need to be most organised. It feels like the early eighties again - but with much less ammunition.

\section{Conclusion}

This paper has examined the persistent relationship between the development of sociology in the UK and the organisation of the labour and trade union movement. This provides an example of 'public sociology' in operation. It also draws attention to variants in the form that this public engagement has taken. Burawoy has identified ways in which this can take place from the top and from the bottom. In the UK 'public sociology from above' has had a strong presence, especially during periods of Labour administration. The London School of Economics has been central to this, seen most clearly in the role Lord Giddens played in the development of the 'Third Way' for the New Labour government. 'Public sociology from below' has been more prolific and this engagement has had a major impact on the content and emphasis of the sociology of work across the period.

The strong presence of a public sociology of this kind in the UK relates to a number of factors. From the beginning of the period the subject has interfaced with a civil society in which the Labour and Communist Parties have had strong memberships, as have a number of Trotskyist groups. Across the period the 'grand narrative' has been one of imperial decline and long term crisis. 'Labour' was seen to be at the centre of this crisis and this was exemplified in the intervention of the IMF in 1976 and the changes in state policy that followed. Sociology was established across university departments in the UK in the 1960s. As a consequence of this 'late development' the pressure for professionalisation took place during years of heightened class struggle and political conflict which were drawn into events often seeing the labour movement as a major audience for their work.

This weak professional control also encouraged collaboration and involvement with other disciplines. This 'openness', while positive, also contributed to the ease with which sociology was practiced outside of sociology departments. This has been most debilitating for the study of work and labour which has been increasingly practiced within Business Schools.

Most recently the New Labour Government, and the decline in overt class struggle has seen a significant fading of interest in within Sociology departments of issues relating to work and the labour movement. This is all the more troubling given the enormity of the current financial crisis and its impact upon public expenditure. There are signs of a reawakening however, most often though links with geography and other disciplines.

\section{ACKNOWLEDGEMENTS}

My thanks to Steve Davies, Tony Elgar, Tony Lane, Peter McMylor and Gareth Rees for their comments on this piece, and to Rhys Davies for his help with Figure 1. 


\section{NOTES}

1. The dispute related to a film processing plant in North London employing a largely female Asian labour force, some of whom were members of the technicians' union APEX. After striking over wages and conditions a third of the labour force was sacked. Postal workers broke the conditions of the Post Office Act 1955 to boycott Grunwick mail; several major mass picketing events were organised including large delegations from the

coalfields; the Labour Government was also supportive and eventually appointed Lord Scarman to conduct an Inquiry. The Scarman Report recommended that the employer should recognise the union. The employer refused and his appeal to the House of Lords was upheld. The dispute became one of the elements that framed the Tory Party's approach to trade unionism after 1979.

2. In this, oddly enough, the TUC and others have found data from the WERS surveys illuminating: most significantly the finding that most non-members have never been approached or asked to join a union.

\section{REFERENCES}

Academy of Social Sciences (2003) Great Expectations: The Social Sciences in Britain, Commission on the Social Sciences.

Austrin, T. and Beynon, H. (1978) 'Gobal Outpost: Multinational Organisations in the North East of England' Working Paper, University of Durham.

Baldry, C., Haworth, N., Henderson. S. and Ramsay, H (1983a) 'Fighting Multinational Power: Massey Ferguson's Plant in Kilmarnock', Capital and Class 20: 157-166.

Baldry, C., Haworth, N., Henderson, S. and Ramsay, H. (1983b), 'Addendum', Capital and Class 21: 134-135.

Beckett, A. (2009) When the Lights Went Out: Britain in the Seventies. London: Faber.

Beynon, H. (1968) 'A Wildcat Strike', New Society, September 15.

Beynon, H. (1975) Working For Ford. London: Penguin Books.

Beynon, H. (1978) What Happened at Speke. Liverpool: TGWU.

Beynon, H. and Wainwright H. (1983) The Workers Report on Vickers. London: Pluto Press. 
Beynon, H. (ed) (1985) Digging Deeper: Issues in the Miners Strike. New York: Verso

Beynon, H. (2007) 'Extended View: Issues of Class, Ethnicity and Migration in a London Borough', Sage Race Relations Abstracts 32(3): 30-43.

Braverman, H. (1974) Labour and Monopoly Capitalism: The Degradation of Work in the Twentieth Century. New York: Monthy Review Press.

Brennan,T., Cooney, E.W. and Pollins, H. (1955) Social Change in South West Wales. London: Watts

Brown, R. and Brannen,P. (1970) 'Social Relations and Social Perspectives Amongst Ship Building Workers - A Preliminary Statement', Parts 1 and 2, Sociology 4(1): 71-84; 4(2): 197-211.

Burk, K. and Cairncross, A. (1992) Good-bye Great Britain: The 1976 IMF Crisis. New York: Palgrave Macmillan.

Cavendish (1982) Women on the Line. London: Routledge and Kegan Paul.

Cavendish, R. (1982) Women on the Line. London: Routledge and Kegan Paul.

C.D.P. Inter-project Editorial Team (1977) Gilding the Ghetto. London: Community Development Project.

Coates, K. and Silburn, P. (1970) Poverty: The Forgotten Englishmen. Harmonsworth: Penguin.

Cunnison, S. and Stageman, J. (1994) Feminising the Unions. Aldershot: Avebury.

Davies, S. (2010) The People's Inquiry into the Public Library Service. London: UNISON

Dennis, N, Henriques, H., and Slaughter, C. (1957) Coal is Our Life. London: Eyre and Spottiswood.

Dench, G., Gavron, K. and Young, M. (2006) The New East End: Kinship, Race and Conflict. London: Profile Books.

Fairbrother, P. (2000) Trade Unions at the Cross Roads. London: Mansell.

Frankenberg, R. (1957) Village on the Border. London: Cohen and West.

Gardner, N. (1988) Decade of Discontent: The Changing British Economy Since 1973. London: Blackwell. 
Giddens, A. (1998) The Third Way: The Renewal of Social Democracy. Cambridge: Polity Press.

Goldthorpe, J.H., Lockwood, D., Beckhoffer, F. and Platt, J. (1968a) The Affluent Worker: Industrial Attitudes and Behaviour. Cambridge: Cambridge University Press.

Goldthorpe, J.H., Lockwood, D., Beckhoffer, F. and Platt, J. (1968b) The Affluent Worker: Political Attitudes and Behaviour. Cambridge: Cambridge University Press.

Goldthorpe, J.H., Lockwood, D., Beckhoffer, F. and Platt, J. (1969) The Affluent Worker in the Class Structure. Cambridge: Cambridge University Press.

Hall, S. and Jacques, M. (eds) (1983) The Politics of Thatcherism. London: Lawrence and Wishart.

Heery, E. (2005) 'Restoring Lost Powers', Renewal 13(1) 20-26.

Hoggart, R. (1957) Uses of Literacy. London: Chatto and Windus.

Hyman, R. (1972) Strikes. London: Fontana Collins.

Hyman, R. and Price, R. (eds) (1983) The New Working Class? White Collar Workers and Their Organisations. London: Macmillan.

Lane,T. and Roberts, K. (1971) Strike at Pilkingtons. London: Fontana Collins.

Lane, T. (1982) 'We're Talking about a Closure Movement', in Rainnie, A. and Stirling, J. (eds) Plant Closure: The Trade Union Response, Occasional Paper, Newcastle Upon Tyne Polytechnic.

London to Edinburgh Weekend Return Group (1979) In and Against the State. London: CSE.

Lockwood, D. (1966) 'Sources of Variation in Working Class Images of Society', Sociological Review 14(3): 249-267.

Michels R.W.E. (1959) Political Parties. Mineola: Dover Publications.

Nichols, T. and Armstrong, P. (1972) Safety or Profit. Bristol: Falling Wall Press.

Nichols, T. (1986) The British Worker Question. London: Routledge and Kegan Paul.

Nichols, T. (1997) The Sociology of Industrial Injury. New York: Routledge. 
Pollert, A. (1981) Girls, Wives, Factory Lives. London: Macmillan.

Roberts, I. (1999) 'Richard Brown and British Sociology, in Beynon, H. and Glavanis, P. (eds) Patterns of Social Inequality: Essays for Richard Brown. London: Longmans.

Rose, J. (2001) The Intellectual Life of the British Working Classes. New Haven: Yale University Press.

Savage, M. and Burrows, R. (2007) 'The Coming Crisis of Empirical Sociology', Sociology 41(5): 885-99.

Savage, M. (2010) Identities and Social Change in Britain Since 1940: The Politics of Method. Oxford: Oxford University Press.

Stacy M. (1960) Tradition and Change: A Study in Banbury. Oxford: Oxford University Press.

Stirling, J. (2001) 'Britain at Work: Letting the Facts Speak for Themselves', Capital and Class 73(Spring): 173-180.

Thompson, E.P. (1963) Making of the English Working Class. New York: Pelican.

Turnbull, P., Woolfson, C. and Kelly, J. (1992) Dock Strike: Restructuring the British Ports. Surrey: Avebury.

Turner (1963) The Trend in Strikes. Leeds: Leeds University Press.

Turner, H.A., (1969) Is Britain Really Strike-Prone? Cambridge: Cambridge University Press.

Turner, H.A., Clack, G. and Roberts, G. (1967) Labour Relations in the Motor Industry. London: Allen and Unwin.

Turner, R. (2000) Coal Was Our Life. Sheffield: Sheffield Hallam University Press.

University of Liverpool Department of Social Sciences (1954) The Dockworker: An Analysis of Conditions of Employment and Industrial Relations in the Port of Manchester. Liverpool: Liverpool University Press.

Walby, S. (1986) Patriarchy at Work. Cambridge: Polity Press.

Wills, J. (2002) Union Futures: Building Networked Trade Unionism in the UK. Fabian Ideas Pamphlet. 
Wills, J. and Datta, K. (2010) Global Cities at Work: New Migrant Divisions of Labour. London: Pluto.

Wilmott, P. and Young, M. (1957) Family and Kinship in East London. New York: Penguin Books

\section{BIOGRAPHICAL NOTE}

Huw Beynon is Professor in the School of Social Sciences at Cardiff University, Wales. 